\title{
Spectrophotometric Determinations of Chloroplastidic Pigments in Physalis angulata L. Leaves Using Different Methodologies
}

\author{
Tamara Torres Tanan ${ }^{1}$, Marilza Neves do Nascimento ${ }^{2}$, Romeu da Silva Leite ${ }^{2} \&$ David Santana Guimarães ${ }^{2}$ \\ ${ }^{1}$ Potsgraduate Program in Plant Genetic Resources, Universidade Estadual de Feira de Santana, Feira de Santana, \\ BA, Brazil \\ ${ }^{2}$ Department of Biological Sciences, Universidade Estadual de Feira de Santana, Feira de Santana, BA, Brazil \\ Correspondence: Tamara Torres Tanan, Potsgraduate Program in Plant Genetic Resources, Universidade Estadual \\ de Feira de Santana, Av. Transnordestina, s/n, Labio, Novo Horizonte, Feira de Santana, BA, CEP: 44036900, \\ Brazil. E-mail: tamara.tanan@yahoo.com.br
}

Received: August 21, 2017

Accepted: September 21, $2017 \quad$ Online Published: October 15, 2017

doi:10.5539/jas.v9n11p117

URL: https://doi.org/10.5539/jas.v9n11p117

\begin{abstract}
The aim of this study was to compare different protocols for extraction and quantification of photosynthetic pigments, considering different solvents, extraction time and temperature, to determine the best methodology for Physalis angulata L. leaves. The efficiency of immersion of leaf discs in $95 \%$ ethanol, $80 \%$ acetone and dimethyl sulfoxide (DMSO) was evaluated for 24, 48 and 72 hours. The effect of temperature on extraction with DMSO was also evaluated, with the samples incubated at room temperature and in a water bath at $65{ }^{\circ} \mathrm{C}$. These protocols were compared with the classical methods of plant tissue maceration in $80 \%$ acetone followed by filtration, which proved to be the most efficient for Physalis angulata plants and indicated for use in the laboratory. The use of high temperatures $\left(65^{\circ} \mathrm{C}\right)$ is not necessary for the chlorophyll extraction process with DMSO, the room temperature is most efficient in the extraction of carotenoids. Considering the total chlorophyll content, the leaf discs immersion technique in a solvent is acceptable, with $95 \%$ ethanol and 24 hours incubation and the most economically viable alternative.
\end{abstract}

Keywords: acetone, dimethyl sulfoxide, ethanol, solvents

\section{Introduction}

Chlorophylls are the most abundant natural pigments found in plants. Studies show that chlorophyllian pigments are the same in a wide variety of plants, and the apparent differences in plant color due to the presence and distribution of other associated pigments (Streit, Canterle, Canto, \& Hecktheuer, 2005; Von Elbe, 2000). The chlorophyll $\alpha$ is the pigment used to perform the photochemical step, corresponding to $75 \%$ of the total green pigments in plants. The other pigments, known as accessory pigments such as chlorophyll $\beta$ and carotenoids, aid in the light absorption and in the transfer of radiant energy to the reaction centers (Taiz \& Zeiger, 2004).

The photosynthetic pigments found in chloroplasts and are responsible for the conversion of light radiation into energy, such as ATP and NADPH, because of that, closely related to the photosynthetic efficiency of plants and primary productivity (Taiz \& Zeiger, 2004). The determination of the leaf pigment content is an important tool for studies of plant physiology, whether for characterization of the material, for distinguishing treatments or the interaction between plants and environmental factors (Lambers, Chapin, \& Pons, 1998). How nitrogen is a constituent of the chlorophyll molecule, the content of this pigment in the leaf also used to predict the nutritional level of nitrogen in plants (Silveira, Braz, \& Didonet, 2003).

The extraction and quantification of the photosynthetic pigments based on the absorbance and reflectance properties of the leaf constituents, which can be a destructive method or not (Lichtenthaler, 1987). Because the fragile (non-covalent) bonds between the chlorophyll molecules, these can be disrupted by the use of organic solvents, and polar once such as acetone, ethanol and dimethylformamide the most effective (Streit et al., 2005). The use of dimethyl sulfoxide (DMSO) is efficient, as well, for complete extraction of the pigments, easier to use, since it only requires immersion of the foliar material in a known volume of this solvent (Barnes, Balaguer, Manrique, Elvira, \& Davison, 1992). The choice of the ideal method for chlorophyll extraction will depend on 
the nature, polarity and purity of the solvent, the temperature and the incubation time, and the correct equations used to calculate chlorophyll concentrations (Ritchie, 2008; Tait \& Hik, 2003).

The morphological and anatomical characteristics of the leaves of different species also influence the extraction process of photosynthetic pigments, which requires evaluating the solvent efficiency. In some fruits, such as Ficus carica, Diospyros kaki and Prunus persica, it has been reported higher efficiency for extraction using $80 \%$ acetone (Barbosa, Scopel, \& Vieira, 2008), In Vittis vinifera the DMSO was more effective when compared to $80 \%$ acetone (Santos et al., 2007). In other cases, there is no difference in the use of different solvents, such as pineapple leaves (Ananas comosus) (Barboza, Portes, \& Teixeira, 2008).

The Physalis angulata L. is a fruit tree, belonging to the Solanaceae family, characterized by sweet taste fruits with a high nutraceutical value, and which stands out for the production of secondary metabolites with wide medicinal potential (Tomassini, Barbi, Ribeiro, \& Xavier, 2000; Lorenzi \& Matos, 2008). Despite the importance of the species, it lacks basic studies related to physiology, such as the extraction and quantification of photosynthetic pigments. Some studies that use chlorophyll content to distinguish between treatments in species of Physalis commonly use 80\% acetone (Bertoncelli, Alamino, Oliveira, Marchesan, \& Loss, 2015; Passos, 2013), however, there is no evaluation about the efficiency of different solvents for any species of the genus. Arruda et al. (2014) found higher extraction efficiency with $80 \%$ acetone for Solanum paniculatum, a species of the same $P$. angulata family.

The quantity of these pigments varies with the plant species, which demands methodological adjustments for the extraction and conservation of these pigments become efficiently. Thus, this work aims to compare the different protocols for extraction and quantification of photosynthetic pigments, considering different solvents, extraction time and temperature to determine the best methodology for use in Physalis angulata leaves.

\section{Method}

This work was performed at the Experimental Unit Horto Florestal of State University of Feira de Santana (UEFS), Brazil, in March 2017.

The Physalis angulata leaf samples obtained from cultivated plants in a hydroponic system with Sarruge's (1975) nutrient solution modified for the Physalis growth (Leite, Tanan, Nascimento, Oliveira, \& Abreu, 2017). Eight randomly selected plants used, from which the first pair of fully expanded leaves collected to measure chloroplastidic pigment contents. Twelve $10 \mathrm{~mm}$ diameter discs were cut from each leaf and immediately transferred to test tubes wrapped with aluminum foil to exclude light, containing $5 \mathrm{~mL}$ of the extractors evaluated.

The effect of three different solvents: $80 \%$ acetone, $95 \%$ ethanol and dimethylsulfoxide (DMSO) and, three incubation periods: 24,48 and 72 hours were analyzed. The tubes were sealed and kept in the dark at room temperature $\left( \pm 25^{\circ} \mathrm{C}\right)$. At the same time, the effect of the temperature on extraction with DMSO evaluated, with the tubes placed in a water bath at $65^{\circ} \mathrm{C}$ for 1 hour and the readings performed immediately and after 24 hours of incubation at room temperature. For comparison, chloroplastidic pigments extracted from the same leaves by vegetal tissue maceration and subsequent filtration using $80 \%$ acetone as solvent (Arnon, 1949).

After each incubation period, the absorbance of the samples was determined using quartz cuvettes in a double beam spectrophotometer (FEMTO 800XI). The wavelengths varied with the solvent used and the contents of chlorophyll $\alpha, \beta$, total $(\alpha+\beta)$ and carotenoids were calculated according to the equations proposed by Lichtenthaler and Wellburn (1983) for 80\% acetone, by Lichtenthaler (1987) for ethanol and by Wellburn (1994) for DMSO. The experimental design was completely randomized, with three replicates, taking one qualitative factor (extraction method) and another quantitative one (extraction time). The quantitative factor was analyzed per non-linear regression using SigmaPlot software v.11.0 (Systat Software Inc., Chicago, USA), while the qualitative one was submitted to analysis of variance. The Tukey test was applied to compare means with 5\% significance using the software Sisvar v.5.3 (Ferreira, 2008).

\section{Results and Discussion}

The concentrations of the chloroplastidic pigments over the extraction time in P. angulata leaves are shown in Figure 1. In relation to the time required for chlorophyll extraction, $95 \%$ ethanol and DMSO were faster, being efficient with 24 hours of incubation. For $80 \%$ acetone the time required was 48 hours, and after this period, there was no difference in the concentrations, evidencing the complete extraction of the pigments. With both solvents used, the data were set for the same model, corresponding to a rectangular hyperbole; the adjustments were highly efficient, as demonstrated by $\mathrm{R}^{2}$ values above 0.95 obtained for chlorophylls, except carotenoids. 
Similar result to Barbieri Junior, Rossiello, Morenz, and Ribeiro (2010) with Tifton 85-grass leaves for chlorophyll with both extractors.

The chlorophyll content $\alpha, \beta$ and total $(\alpha+\beta)$ extracted with the use of DMSO had no significant difference when the samples were exposed at $65^{\circ} \mathrm{C}$, with $1 \mathrm{~h}$ or $24 \mathrm{~h}$ of incubation, compared to the extraction done at room temperature, showing that for $P$. angulata the extraction process does not require high temperatures, which makes it simpler (Table 1). Tait and Hik (2003) also found that it was not necessary to heat up to $65{ }^{\circ} \mathrm{C}$ for the extraction of chlorophylls in grasses. Higher temperatures (above $40^{\circ} \mathrm{C}$ ) are required for the complete extraction of chlorophyll in lichens, thick leaves and highly cutinized (Barnes et al., 1992; Tait \& Hik, 2003), which is not the case of $P$. angulata. In addition, the incubation of leaf discs in DMSO at room temperature also favored the extraction of carotenoids.
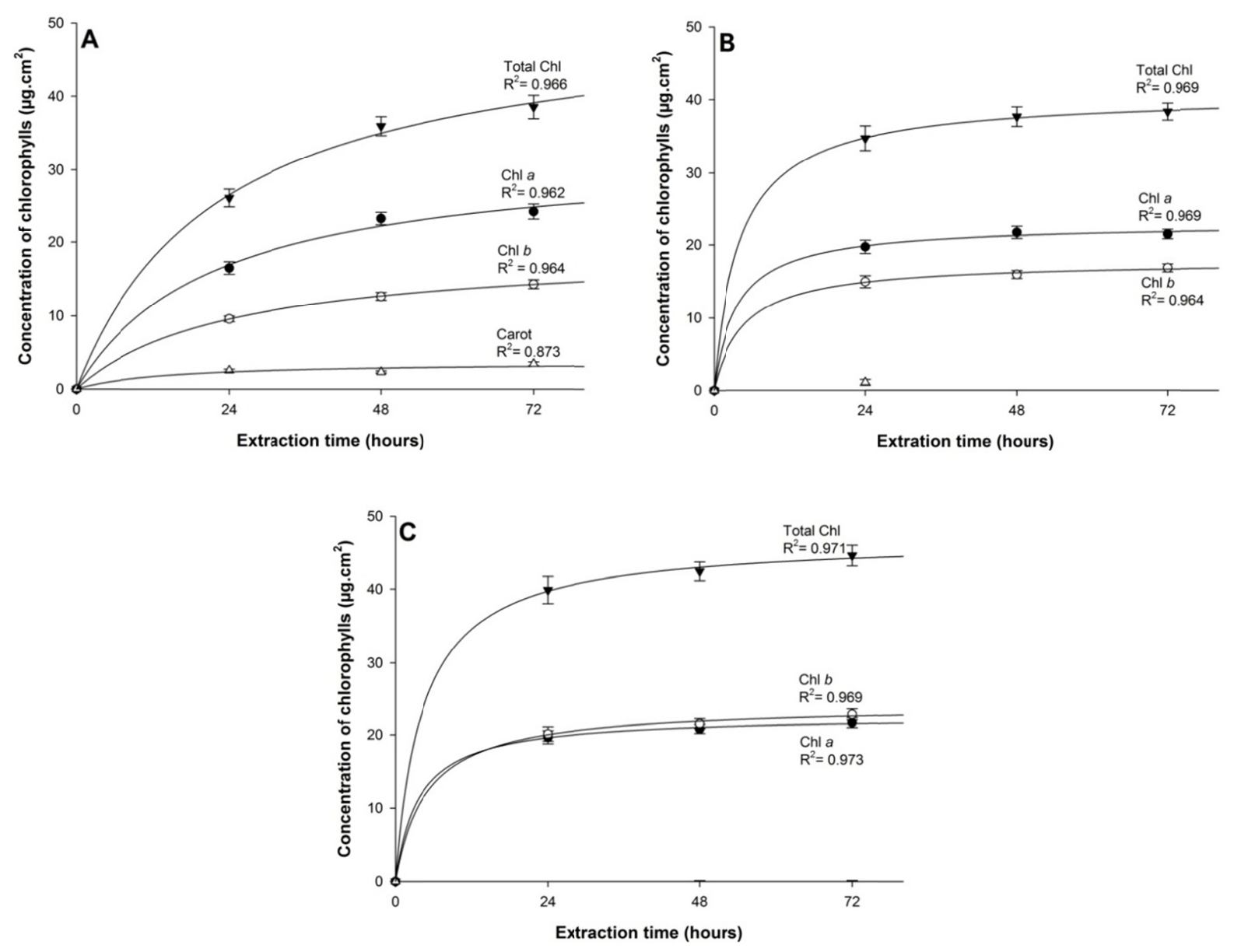

Figure 1. Chlorophyll $\alpha, \beta$ and total $(\alpha+\beta)$ content of Physalis angulata leaves extracted from different solvents. A - $80 \%$ Acetone, B - DMSO, C - $95 \%$ Ethanol

Considering the method and the solvent used and the best incubation time observed, the results differed among pigment classes (Table 1). The chlorophyll $\alpha$ concentration using the methodology of disc leaf immersion in solvent did not present significant differences among the extractors used. However, in comparison with the classical method of leaf maceration in $80 \%$ acetone (Arnon, 1949), it was observed that this method differed significantly from the other methodologies evaluated, with higher values. Maceration of leaf tissue easily breaks the bonds between chlorophyll molecules (Streit et al., 2005), which may lead to an increase in extraction using this technique. These data are different from those found by other authors where DMSO immersion leaf discs were more efficient than the other methods (Barbieri Junior et al., 2010; Cruz et al., 2007). 
Table 1. Mean content of photosynthetic pigments extracted from leaves of Physalis angulata by different solvents and methodologies

\begin{tabular}{lllll}
\hline Method & Chl $\boldsymbol{a}\left(\boldsymbol{\mu g} \mathbf{c m}^{2}\right)$ & $\mathbf{C h l} \boldsymbol{b}\left(\boldsymbol{\mu g} \mathbf{c m}^{2}\right)$ & Carotenoids $\left(\boldsymbol{\mu g} \mathbf{~ c m}^{2}\right)$ & Total Chl $\left(\boldsymbol{\mu g} \mathbf{c m}^{2}\right)$ \\
\hline $80 \%$ Acetone with maceration & $28.67 \mathrm{a}$ & $24.56 \mathrm{a}$ & $1.61 \mathrm{ab}$ & $53.23 \mathrm{a}$ \\
$80 \%$ Acetone without maceration & $23.29 \mathrm{~b}$ & $12.64 \mathrm{c}$ & $2.35 \mathrm{a}$ & $35.94 \mathrm{~b}$ \\
$95 \%$ Ethanol & $20.86 \mathrm{~b}$ & $21.55 \mathrm{ab}$ & $0.18 \mathrm{~b}$ & $42.42 \mathrm{ab}$ \\
DMSO & $21.77 \mathrm{~b}$ & $15.97 \mathrm{bc}$ & $1.83 \mathrm{a}$ & $37.74 \mathrm{~b}$ \\
DMSO $65^{\circ} \mathrm{C}$ & $21.89 \mathrm{~b}$ & $18.40 \mathrm{abc}$ & $0.14 \mathrm{~b}$ & $40.29 \mathrm{~b}$ \\
DMSO $65^{\circ} \mathrm{C}+24 \mathrm{~h}$ & $20.95 \mathrm{~b}$ & $19.28 \mathrm{abc}$ & $0.11 \mathrm{~b}$ & $40.24 \mathrm{~b}$ \\
\hline
\end{tabular}

Note. Means followed by the same letter in the column did not differ significantly by the Tukey's test $(\mathrm{P}<0.05)$.

For extraction of chlorophyll $\beta$, several methods were efficient, with the highest values observed with the $80 \%$ acetone maceration, followed by $95 \%$ ethanol immersion leaf disks and DMSO at $65{ }^{\circ} \mathrm{C}$ after $1 \mathrm{~h}$ and $24 \mathrm{~h}$ of incubation, with no statistical difference between them. The opposite was observed for the carotenoid content, where the disks immersed in $80 \%$ acetone and DMSO at room temperature had the highest concentrations (Table 1). The total carotenoid content can be easily determined by measuring the maximum absorption of chlorophyll $\alpha$ and $\beta$, and additionally the maximum absorption at the wavelength of $470-480 \mathrm{~nm}$. Thus, a correct determination of carotenoids requires the prior and correct determination of the concentration of chlorophyll $\beta$. If the chlorophyll $\beta$ level is overestimated, the resulting values for the total carotenoids will be very low and vice versa (Lichtenthaler, 1987).

The differences between solvent efficiency depend on the kind of plant and the structure of the cell wall (Dere, Günes, \& Sivaci, 1998). Different plant tissues react to a different kind of extractor. Some of them are inefficient, some are highly efficient, but still require maceration and centrifugation or filtration, and some require immersion of the tissue in aqueous solvents from which the pigments are extracted (Wellburn, 1994). For $P$. angulata plants, considering the total chlorophyll content $(\alpha+\beta)$, the highest extraction efficiency was obtained using the $80 \%$ acetone maceration technique, followed by $95 \%$ ethanol leaf discs immersion (Table 1), however without statistical differences between them.

In order to determine the best method other factors should be considered. Acetone is not suitable for field work due to volatility, propensity to leak from containers, flammability and despite the best results observed, it is permissible to lose a certain precision and use another method under field conditions, when it involves the comparison of a high number of treatments and repetitions (Ritchie, 2008; Barbieri Junior et al., 2010). Protocols, where part of the plant tissue is immersed in a solvent, are recommended due to the practicality, the possibility of preparing a large number of samples in a short time. In addition, the spectrophotometric readings can be made after a few days in extracts stored in a dark and cool place (Hiscox \& Israelstam, 1979; Barnes et al., 1992).

Several authors recommend the use of DMSO (Cruz et al., 2007; Santos et al., 2007; Pompelli et al., 2013). Has high diffusion capacity through semipermeable membranes, also recognized for its efficiency as proteins carrier that provides agility in the process, the extracts prepared with DMSO being more stable than those are prepared whit acetone (Barnes et al., 1992; Cruz et al., 2007). However, some authors report the inefficiency of DMSO to extract in vivo plants chlorophyll $\beta$ (Barnes et al., 1992; Shinano et al., 1996). Ehanol is more practical, easier to transport and handle, and cheaper than other solvents evaluated. However, the absorption peaks of chlorophyll $\alpha$ are usually smaller and wider and may interfere with the absorbance of chlorophyll $\beta$, underestimating the pigments concentration in leaf extracts (Ritchie, 2008; Pompelli et al., 2013).

\section{Conclusion}

Several factors should be considered at moment to choose the chloroplastidic pigments extraction method. The use of the $80 \%$ acetone tissue maceration protocol followed by filtration was the most efficient for Physalis angulata plants, indicated for use in the laboratory. In field conditions, the immersion technique of foliar disks in $95 \%$ ethanol and 24 hours incubation is acceptable and the most practicable economically.

\section{References}

Arnon, D. I. (1949). Copper enzymes in isolated chloroplasts. Polyphenoloxidase in Beta vulgaris. Plant Physiology, 24(1), 1-15. https://doi.org/10.1104/pp.24.1.1 
Arruda, C. T. B. S., Barbosa, A., Espinheira, I. H. L., Lopes, S. S. M., Silva, A. B., \& Mapeli A. M. (2014). Uso de diferentes métodos na determinação dos teores de clorofila em Solanum paniculatum no Cerrado do Oeste da Bahia. $1^{a}$ Jornada de Química da UFOB, Anais... Barreiras.

Barbieri Junior, E., Rossiello, R. O. P., Morenz, M. J. F., \& Ribeiro, R. C. (2010). Comparação de métodos diretos de extração e quantificação dos teores de clorofilas em folhas do capim-Tifton 85. Ciência Rural, 40, 633-636. https://doi.org/10.1590/S0103-84782010000300022

Barbosa, J. Z., Scopel, W., \& Vieira, M. L. (2008). Procedimentos para extração de pigmentos fotossintetizantes em espécies frutíferas. Evidência, 8(1-2), 29-42. https://doi.org/10.18593/eba.v8i1-2.1871

Barboza, S. B. S. C., Portes, T. A., \& Teixeira, J. B. (2008). Diferentes métodos para extração de clorofilas em folhas de abacaxi cultivadas in vitro. Aracaju: Departamento de Desenvolvimento Agropecuário de Sergipe, Embrapa Tabuleiros Costeiros.

Barnes, J. D., Balaguer, L., Manrique, E., Elvira, S., \& Davison, W. (1992). A reappraisal of the use of DMSO for the extraction and determination of chorophylls $\mathrm{a}$ and $\mathrm{b}$ in lichens and higher plants. Environmental and Experimental Botany, 32(2), 85-100. https://doi.org/10.1016/0098-8472(92)90034-Y

Bertoncelli, D. J., Alamino, D. A., Oliveira, M. C., Marchesan, E. D., \& Loss, E. M. C. (2015). Aspectos bioquímicos do desenvolvimento inicial de plantas de fisális sob diferentes condições luminosas. Brazilian Journal of Applied Technology for Agricultural Science, 8(1), 37-46. https://doi.org/10.5935/ PAeT.V8.N1.04

Cruz, A. C. F., Santos, R. P., Iarema, L., Fernandes, K. R. G., Kuki, K. N., Araújo, R. F., \& Otoni, W. C. (2007). Métodos comparativos na extração de pigmentos foliares de três híbridos de Bixa orellana L. Revista Brasileira de Biociencias, 5(Supl. 2), 777-779. Retrieved from http://www.ufrgs.br/seerbio/ojs/index.php/ $\mathrm{rbb} /$ article/view/658/557

Dere, S., Günes, T., \& Sivaci, R. (1998). Spectrophotometric determination of chlorophyll-a, b and total carotenoid contents of some algae species using different solvents. Turkish Journal of Botany, 22, 13-17. Retrieved from http://citeseerx.ist.psu.edu/viewdoc/download?doi=10.1.1.617.505\&rep=rep1\&type=pdf

Ferreira, D. F. (2008). SISVAR: um programa para análises e ensino de estatística. Revista Symposium, 6, 36-41.

Hiscox, J. D., \& Israelstam, G. F. (1979). A method for the extraction of chlorophyll from leaf tissue without maceration. Canadian Journal of Botany, 57(12), 1332-1334. https://doi.org/10.1139/b79-163

Lambers, J., Chapin, F. S., \& Pons, T. L. (1998). Plant physiological ecology. New York: Springer-Verlag. https://doi.org/10.1007/978-1-4757-2855-2

Leite, R. S., Tanan, T. T., Nascimento, M. N., Oliveira, L. M., \& Abreu, P. A. S. (2017). Hydroponic cultivation of Physalis angulata L.: Growth and production under nitrogen doses. Pesquisa Agropecuária Tropical, 47(2), 145-151. https://doi.org/10.1590/1983-40632016v4744652

Lichtenthaler, H. K. (1987). Chlorophylls and carotenoids: Pigments of photosynthetic biomembranes. Methods Enzymology, 148, 350-382. https://doi.org/10.1016/0076-6879(87)48036-1

Lichtenthaler, H. K., \& Wellburn, A. R. (1983). Determination of Total Carotenoids and Chlorophylls A and B of Leaf in Different Solvents. Biochemical Society Transactions, 11, 591-592. https://doi.org/10.1042/ bst0110591

Lorenzi, H., \& Matos, M. (2008). Plantas medicinais no Brasil: nativas e exóticas cultivadas (2nd ed.). Nova Odessa, SP: Plantarum.

Passos, A. I. dos. (2013). Adubação e assimilação de nitrogênio em duas espécies de Physalis (Master's thesis, Universidade Tecnológica Federal do Paraná, Pato Branco, Brazil). Retrieved from http://repositorio. utfpr.edu.br/jspui/handle/1/623

Pompelli, M. F., França, S. C., Tigre, S. C., Oliveira, M. T., Sacilot, M., \& Pereira, E. C. (2013). Spectrophotometric determinations of chloroplastidic pigments in acetone, ethanol and dimethylsulphoxide, Revista Brasileira de Biociências, 11(1), 52-58. Retrieved from http://www.ufrgs.br/seerbio/ojs/index.php/ $\mathrm{rbb} /$ article/view/2281

Ritchie, R. J. (2008). Universal chlorophyll equations for estimating chlorophylls a, b, c, and d and total chlorophylls in natural assemblages of photosynthetic organisms using acetone, methanol, or ethanol solvents. Photosynthetica, 46(1), 115-126. https://doi.org/10.1007/s11099-008-0019-7 
Santos, R. P., Cruz, A. C. F., Iarema, L., Fernandes, K. R. G., Kuki, K. N., \& Otoni, W. C. (2007). Avaliação da Eficiência do Dimetilsulfóxido na Extração de Pigmentos Foliares de Vitis vinifera $\times V$. rotundifolia e $V$. riparia Propagadas in vitro. Revista Brasileira de Biociências, 5(Supl. 2), 888-890. Retrieved from http://www.ufrgs.br/seerbio/ojs/index.php/rbb/article/view/733/617

Sarruge, J. R. (1975). Soluções nutritivas. Summna Phytopathologica, Piracicaba, 1(3), 231-233.

Shinano, T., Lei, T. T., Kawamukai, T., Inoue, M. T., Koike, T., \& Tadano, T. (1996). Dimethylsulfoxide method for the extraction of chlorophylls $\mathrm{a}$ and $\mathrm{b}$ from the leaves of wheat, field bean, dwarf bamboo and oak. Photosynthetica, 32, 409-415.

Silveira, P. M., Braz, A. J. B. P., \& Didonet, A. D. (2003). Uso do clorofilômetro como indicador da necessidade de adubação nitrogenada em cobertura no feijoeiro. Pesquisa Agropecuária Brasileira, 38, 1083-1087. https://doi.org/10.1590/S0100-204X2003000900009

Streit, M. N., Canterle, L. P., Canto, M. W., \& Hecktheuer, L. H. H. (2005). As clorofilas. Ciência Rural, 35(3), 748-755. https://doi.org/10.1590/S0103-84782005000300043

Tait, M. A., \& Hik, D. S. (2003). Is dimethylsulfoxide a reliable solvent for extracting chlorophyll under field conditions? Photosynthesis Research, 78(1), 87-91. https://doi.org/10.1023/A:1026045624155

Taiz, L., \& Zieger, E. (2004). Fisiologia Vegetal (3th ed.). Porto Alegre, RS: Artmed.

Tomassini, T. C. B., Barbi, N. S., Ribeiro, I. M., \& Xavier, D. C. D. (2000). Gênero Physalis: Uma revisão sobre vitaesteróides. Química Nova, 23(1), 47-57. https://doi.org/10.1590/S0100-40422000000100011

Von Elbe, J. H. (2000). Colorantes. In O. W. Fennema (Ed.), Química de los alimentos (2nd ed.). Zaragoza: Wisconsin, Madison.

Wellburn, A. R. (1994). The spectral determination of chlorophyll a and b, as well as total carotenoids, using various solvents with spectrophotometers of different resolution. Journal of Plant Physiology, 144, 307-313. https://doi.org/10.1016/S0176-1617(11)81192-2

\section{Copyrights}

Copyright for this article is retained by the author(s), with first publication rights granted to the journal.

This is an open-access article distributed under the terms and conditions of the Creative Commons Attribution license (http://creativecommons.org/licenses/by/4.0/). 